\title{
Exploration on the construction of sub contract security management system for general contracting enterprises
}

\author{
Tao ZHANG ${ }^{1, a}$, Jin-hua $\mathrm{LI}^{2, \mathrm{~b}}$, Dong-xing $\mathrm{LI}^{3, \mathrm{c}}$ \\ ${ }^{1}$ Hebei Vocational College of Rail Transportation, Shijiazhuang, HeBei, 050091, China \\ ${ }^{2}$ Tianjin Chengjian University, Tianjin, 300384, China \\ ${ }^{3}$ Shijiazhuang transit project construction and management co. \\ a370187043@qq.com, 'ljh_162@126.com, 623617878@qq.com
}

\begin{abstract}
Keywords: General contracting enterprise; GB28001-2011 standard; Subcontractor; Safety management

Abstract. Construction site safety accidents more and binary package management related to poor. Through the analysis of the construction general contract enterprise subcontracting problems existing in the safety management, find out the reason, based on the request of Occupational health and safety management systems-Requirements GB28001-2011 (IDT OHSAS 18001:2007), put forward the general contracting enterprise system construction safety management system, from the"leadership responsibility, occupational health and safety policy, planning safety management objectives, responsibility, responsibility and authority, implementation and operation control, inspection and evaluation "several aspects launches the elaboration, in order to reduce safety accidents.
\end{abstract}

Construction engineering subcontracting, refers to the construction enterprises will be the contract of housing construction and municipal infrastructure projects in the engineering or operational services contract to other construction enterprises to complete the activity. Construction is divided into subcontracting engineering sub and labor subcontracting ${ }^{[1]}$. In this paper, we study the general contracting enterprises how to strengthen the engineering subcontract safety management.

\section{Problems and causes in the engineering construction subcontracting}

With the development of the construction industry, general contracting enterprises and a number of subcontracting cooperation to complete the project has become a trend. That specialize in architectural engineering and technology at the same time, bring the problems of safety management in construction site is increasingly urgent. According to statistics, November 2012 to 2015, the national construction injury death an accident to 1758 , the death toll to 2263 people, these accidents more and package safety management related. How to do well the safety management of subcontracting, avoid and reduce the occurrence of safety accidents become construction general contracting enterprises and subcontracting party increasingly pay attention to the problem.

The author and construction industry experts, construction company manager, project manager, sub contracting party manager, construction unit representative and so on in-depth exchanges, analyzed and summarized the main problems and causes of the sub-package safety management are as follows.

\section{Leadership is not enough}

Some business leaders safety production concept of indifference, general contracting business leaders think subcontracting engineering security should by the subcontractor to take full and package of leadership that job security is the total package units, resulting in subcontracting engineering security of a serious shortage of inputs.

Sub package management system is not perfect

In the general contracting enterprise security management agencies in the absence of specialized responsibility for the management of the post or department, the relevant sub contracting party management system is not perfect, poor operability. 
Subcontracting security management mechanism is not perfect, an insufficient number of personnel for the administration of production safety configuration, not fixed in the construction site safety management personnel, no clear division of responsibilities. And even some full-time security officer and special operations personnel are undocumented. Safe production rules and regulations are not perfect, does not conform to the requirements of the some management system and national security laws and regulations, part of operation rules is not standardized.

\section{Subcontractor selection is not strict}

General contracting enterprises by the construction unit or its impact, subcontracting of lax supervision, the construction works subcontracting to does not have corresponding qualifications units. Part of the project Department of the subcontractor selection when no review or review is not standardized, which planted the hidden safety trouble. There is a huge risk of this sub management model.

\section{Sub contract problem}

Total the two sides signed the contract without the use of templates, self draft agreement, contract content is too simple, the terms of the contract is not standardized, contradictory. Lack of some sub contract terms of responsibility for the security, safety margin terms. Some subcontract wrote "subcontractor any security incidents, all sub contractor shall bear", this is does not conform to the law, belong to the invalid provision. Many package contract review becomes a mere formality, and review, which to the enterprise bring greater security risk, extremely easy to cause safety accidents and disputes.

\section{Subcontracting project site management confusion}

Sub contractors in order to reduce the cost, the hiring of temporary staff, professional quality low, to operating personnel before entering without safety education, in front of the construction lack safety disclosure, the lack of systematic and comprehensive safety knowledge, safety skills training, resulting in operating personnel is not the solution of the construction activities exactly what dangerous source, should be how to prevent, lack of the knowledge of emergency, safety accidents are easy to occur. This is the unsafe hidden danger.

Subcontractor selection of materials more consider the price does not pay attention to quality, shoddy, causing the unsafe state of object.

Subcontracting and its safety management mechanism is not perfect, job site safety management confusion. General contracting enterprises to Party A directly specified by the subcontractor safety management weak. Escrow package to the implementation of part of the project department, general contracting enterprises can not play a role in the management of. This is a defect management, which increases the risk of safety management and accident probability.

\section{Evaluation of subcontractor deficiencies}

General contracting enterprise in construction process of subcontracting party safety inspection problems. In the project after the completion of the subcontract performance no track, not for subsequent project cooperation to provide actual reference data.

\section{Strengthening the safety management measures of the subcontractor}

Related subcontractor safety management of all aspects is not independent of the presence of, is a problem of general contracting enterprise safety management system, planning problems, run out of control, due to lack of checks. Therefore, in order to to solve this problem, it is necessary to combine Occupational health and safety management systems-Requirements GB28001-2011 (IDT OHSAS 18001:2007) (hereinafter referred to as the "standard") standard requirements, from the "leadership responsibility, occupational health and safety policy, safety management objectives of the planning, clear responsibilities, responsibility and authority, implementation and operation control, inspection and evaluation" construction subcontractors the whole management system, to conduct a comprehensive management. 


\section{Leadership responsibility}

The standard provides that "top management should take the ultimate responsibility for the management system of occupational health and safety and occupational health and safety".

Relevant regulations: general contracting enterprises will be in accordance with the law construction engineering subcontract to other units, sub contract shall specify the rights of their safety, compulsory. General contracting enterprises and subcontracting bisection bear joint and several liability ${ }^{[2]}$. Subcontractors shall take the from of the general contractor enterprise safety in production management, sub contractors do not obey the management and led to the production safety accidents for the subcontracted projects, production safety, from package bear the primary responsibility. Therefore, general contracting business leadership, package unit leaders to learn the laws and regulations, assume responsibility for its security.

Sense of leadership decided to organize action, only general contracting enterprise leadership, leadership understanding of the construction of a sound subcontracting the importance of safety management system, unified understanding of safety management, to both sides together, do a good job site safety management.

\section{Occupational health and safety policy}

Standard provides that: "top management should be identified and approved the organization of occupational health and safety policy, and ensure the occupational health and safety policy to all control of the organization work personnel, to make it known to the respective occupation health and safety obligations".

General contracting enterprises should be the company's occupational health and safety management policy to reach the company's project department and the sub contracting parties, so that the project department and the subcontractor fully aware of their own occupational health and safety obligations.

\section{Plan safety management objectives}

The standard provides that "the organization shall establish, implement and maintain the occupational health and safety objectives in the form of documents related to its internal functions and levels".

To clear sign a general contracting enterprise safety management objectives and subcontracting safety management goal is to score. For the implementation of safety responsibility system, the full realization of Project Manager Department of safety production management objectives, the project manager and project subcontracting unit is responsible for safe production target management responsibility to shape, such as: Contractor Safety Management objectives can be formulated as: death accident is zero, to prevent serious accidents, to prevent economic loss of 5 million yuan of above of safety production accident. Minor accident does not exceed 3. Construction site general hidden rectification rate should reach $90 \%$ above, major hidden rectification rate reached to $100 \%$. The package to the safety in production goals, requirements for package Security objectives are layer upon layer decomposition, the security responsibilities to the team and individual.

\section{Clear responsibilities, responsibilities and authority}

Provisions of the standard "top management should be clearly assigned duties and responsibilities, grant power to provide effective occupational health and safety management", "the organization shall ensure workplace personnel in the control field bear occupational health and safety responsibility".

\section{To establish and improve the sub package safety management}

Sub of sub in general contracting enterprise management mechanism to explicitly specify a department or post, responsible for the establishment of a safety management system, responsible for subcontract party safety management work, subcontracting party inspection, the signing of the agreement, safety education, safety inspection, performance evaluation. General contracting enterprises to organize new engineering subcontracting plan, project department is responsible for the implementation of sub safety risk management. As a sub contractors, to establish the corresponding safety management mechanism and general contracting enterprises docking, obey the 
general contracting enterprise safety management, the implementation of general contracting enterprises. Such as the use of straight line type structure, the safety management organization structure is simple Single, clear responsibility, unified security command, command convenient, good execution.

\section{To establish and improve the sub package safety management system}

General contracting enterprises must formulate and perfect the subcontract safety management system, including the safety responsibility system, safety education system, safety inspection system, production safety margin system. The production safety margin system, general contracting enterprises can according to sub contract charge party a certain amount of production safety margin. Production safety margin earmarked to implement for construction process in subcontracting party workers safety education, safety skills training, supplies and labor protection and safety protection facilities of acquisition and maintenance, emergency emergency treatment and casualty accident investigation and handling. The subcontract works completed acceptance, factual settlement.

\section{Implement and operation control}

Standards and regulations "the organization shall determine the operations and activities associated with the risk sources that have been identified, the need to implement the necessary control measures, to manage occupational health and safety risks, including change management.For these operations and activities, the organization shall implement and maintain and control measures in the workplace the Contractor related ".

This includes subcontracting party selected strictly, signed a security agreement, identification and evaluation of hazard formulated corresponding countermeasures, safety disclosure, safety education, strictly control the subcontractor personnel comes into play, emergency work.

\section{Strict sub contracting parties to choose}

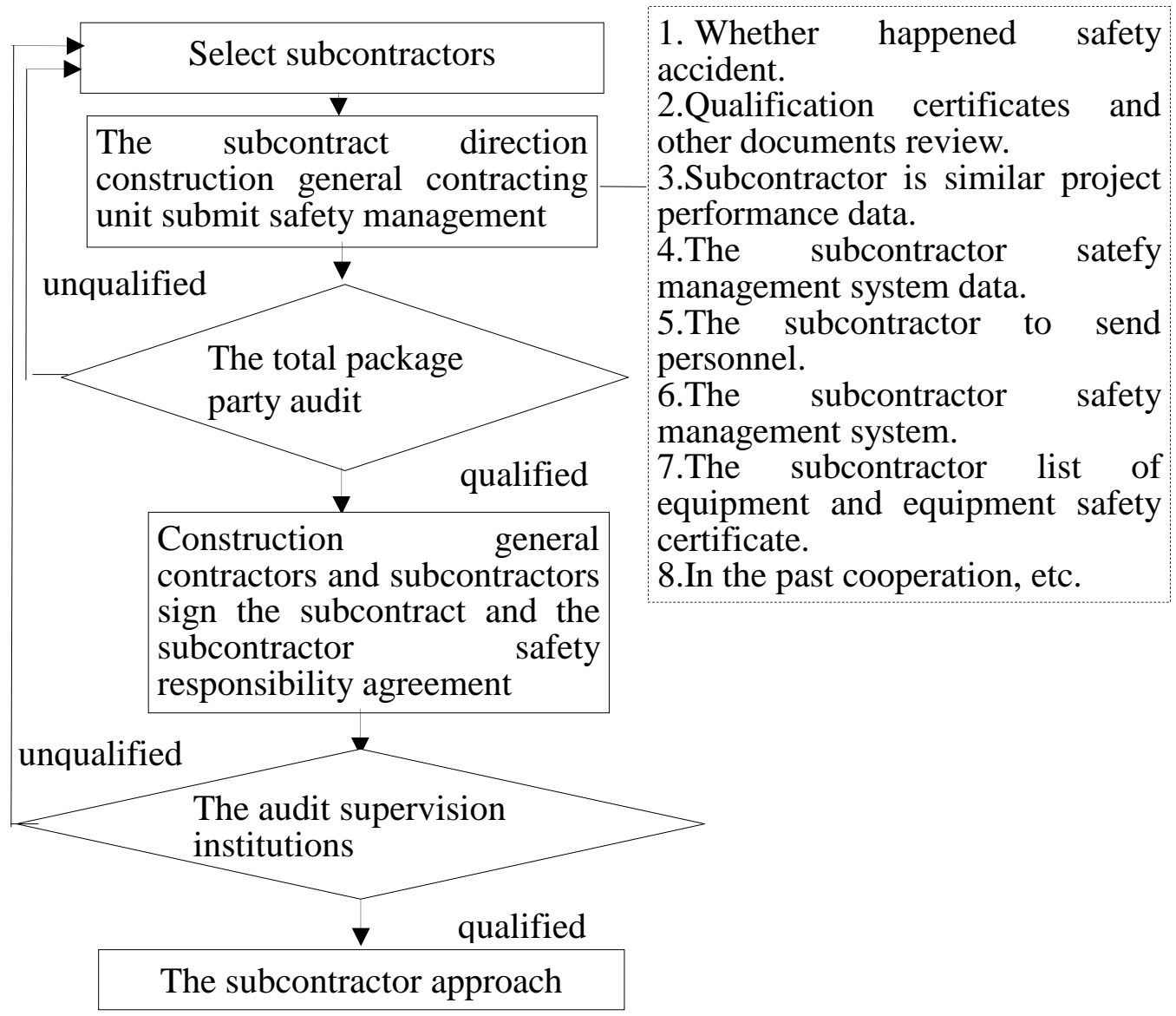

Fig. 1 General contractor subcontractor selection 
Subcontracting of qualified plans to hire qualified without good engineering is a good team dry out. In the signing of the sub contract, according to the subcontract works, merit based selection. The qualified contractors:(1)Safe liability accident;(2)Qualified ${ }^{[3]}$;(3)The similar engineering construction performance;(4)Subcontracting enterprises to be employed by the project manager, technical person in charge, full-time security personnel, special operations personnel qualifications and experience to meet the requirements; (5)In the past, cooperation in engineering, etc.

Once the safety accidents occurred on the subcontractor shall be eliminated. After passing the examination, can be used. For larger sub contract projects, to adopt the tender subcontract, expand the scope of competition, thereby reducing the cost and ensure safety.

\section{Signed a special agreement on safety management}

Standards: "in view of the occupational health and safety risk sources and occupational health and safety management system, the organization shall communicate with the contractor and other visitors entering the workplace".

Once the package subcontracting subcontracting subcontracting of construction subcontracting safety management system must be implemented to both sides of the contract. The total contract enterprises in accordance with the law, the construction project to other units, in the signing of the sub contract, must sign the safety management of special agreement, clearly the two sides in the safe production responsibility, rights and obligations ${ }^{[4]}$. General contracting enterprises have the right to review safety qualification and safety management, in violation of the safety operation regulations, shall be ordered to make rectification work stoppage, sub contractors, safety accident, general contracting enterprises in accordance with the contract agreed to assist the Contractor shall, according to the provisions of reported. Subcontracting party must obey the total package unit management, subcontracting of Responsible for the safety work of the construction site, conscientiously fulfill the sub contract provisions of the safety production responsibility; abide by the general contractor's relevant safety production system, obey the general contractor safety production management.

\section{Organization sub contracting party to identify the risk of construction projects, evaluation,} development strategies

To organize content should in general contracting enterprises subcontracting party approach of subcontracting party site reconnaissance, and subcontracting engineering subcontracting party risk source recognition, the task analysis method, according to the construction process, considering the unsafe factors of unsafe state, the management of defects from may cause the object hit, falling, mechanical injury, electric shock, collapse accident. As a result, comprehensive system of identification of dangerous source. The LEC Method to evaluate significant risk to develop safety measures and implementation, as shown in Figure 2 shows. For project risk larger sub project by subcontract party preparation special safety scheme. The audit of the general contracting enterprises, the company technical person in charge of the approval before the implementation.

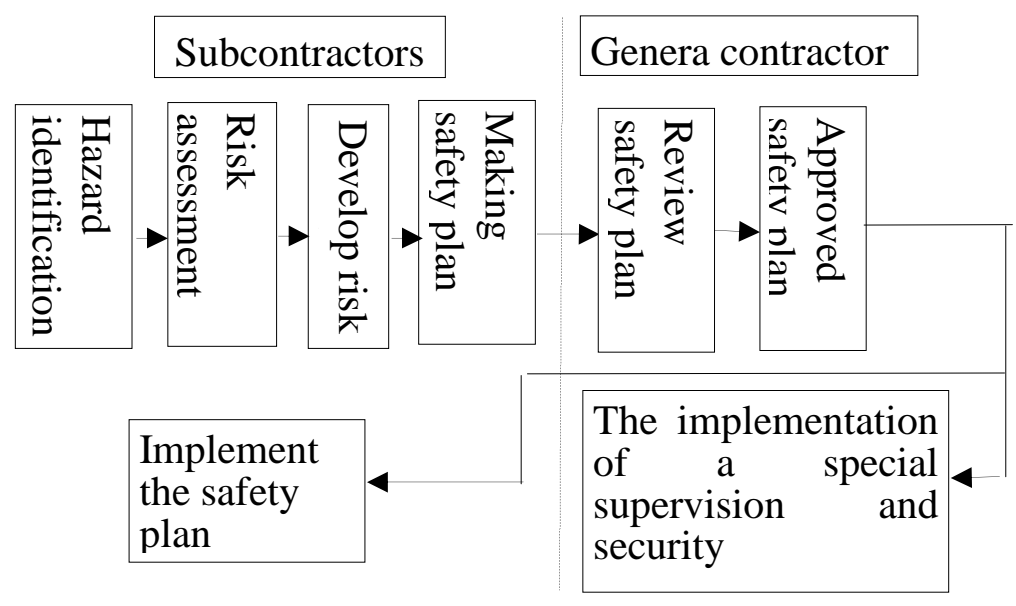

\section{Fig. 2 Risk assessment and control flow chart of risk source identification of subcontractor Ability, training and awareness of subcontractors}

Standard provides that "the organization shall ensure that complete the task has an impact on occupational health and safety of personnel under its control have the corresponding ability and the 
ability should be on the basis of appropriate education, training or experience to determine". Therefore, in order to subcontractor to strengthen the safety education and the subcontractor into the safety management system of the general contractor enterprise. General contracting enterprises should proceed from the needs of the construction site safety, subcontractor management personnel, operations personnel hierarchical safety awareness education and safety knowledge training ${ }^{[5]}$, to enhance their safety skills. In safety disclosure, indicating that workers in its activities in the presence of hazard, prevention measures and emergency measures etc.. Safety disclosure Records must be made by all the construction personnel of the sub project I signed and confirmed, and archived.

\section{Strict control of sub contractors approach staff}

Construction safety management system to strictly control the subcontractor personnel approach. Sub contractors before entering the need to the General Contractor submitted entry personnel list, personnel comes into play, the general contractor should be strictly in accordance with the subcontractor submitted the list one by one to check, especially to check the subcontract project manager, safety management personnel, heavy work and other special types of operation certificate, ID card, all documents to the validity period and retained a copy. If the subcontractor personnel adjustment must be approved by the general contractor, the new adjustment of personnel must have the corresponding qualifications and meet the actual needs of the project.

\section{Organize the sub contracting parties to participate in the emergency drills of the general contracting enterprises}

Construction safety management system, it is necessary to strengthen emergency management. Standard stipulated: "the organization shall also be regularly tested the response of emergency procedures, and appropriate to participate in the" related party, the general contractor should according to the emergency plan to organize emergency drills and asked subcontractor personnel in and subcontractors should be in accordance with the requirements of the total package units, with total package units command, evacuation, material evacuation work.

\section{Inspection and evaluation}

\section{Carry out safety supervision and inspection in the process of subcontracting}

Responsible for standard provides that "the organization shall establish, implement and maintain a procedure of occupational health and safety performance of the routine monitoring and measurement". Construction of the security management system, to strengthen subcontracting party supervision. General contracting units to strengthen subcontracting project safety supervision and guidance, combined with contractors and engineering practice, assign a full-time security staff guidance package management, subcontracting party only to the total contract enterprises, not directly with the supervision units, construction units work. General contracting enterprises should strictly subcontracting engineering itemized inspection, found safe hidden trouble, to take timely measures. In the subcontracting party supervision process, general contractor should strengthen raw material product Tired.

Through strict subcontracting management of project funds, the subcontracting party key process, key positions, key equipment safety risk strict supervision. Thus to prevent the package of illegal subcontract prohibited contracting of construction contracts.

\section{Completes the subcontractor's work performance evaluation}

"In order to fulfill the requirements of compliance with the requirements of laws and regulations, the organization shall regularly evaluate compliance with applicable laws and regulations."

Conscientiously do a good job of performance evaluation, including the enterprise security management institutions, tertiary education, safety training, professional quality, cooperation, accident, law-abiding, package engineering data and safety data transfer, the project safety management. The evaluation of the above results are recorded in the archives, as a reference for the next cooperation.

\section{Conclusions}

"Safety production and Prevention".The general contractor enterprise combining Occupational health and safety management systems-Requirements GB28001-2011(IDT OHSAS 18001:2007), the construction of a comprehensive system of the subcontract and safety management system.Must enhance their enterprise security management at the same time, pay more attention to and strengthen the sub contracting party's safety production management, investigation and security risks, to prevent 
the occurrence of safety accidents.

\section{Acknowledgements}

Thanks to the completion of the work, thanks to the support of the Shijiazhuang transit project construction and management co.!

\section{Literature References}

[1] Meng-chen Li. Research on the construction of construction enterprise project management [J]. Enterprise,2010, (14):20-21,in chinese.

[2] Miao-jun Liang . Contract and subcontract of construction safety in the construction of legal relationship $[\mathrm{N}]$. Construction times, 2011-06-20(004).in chinese.

[3] Rui-gen Xiao. The problems and improvement measures in the construction of the construction safety management [J].Building Safety,2014,(8):47-50,in chinese.

[4] Chun-mei Lin.Construction project subcontracting management of safety data collection[J].Urban Construction Archives, 2013,(5):35-37, in chinese.

[5] Jian-liang Zhou,Dong-ping Fang,Tian-xiang Wang.Safety production management position and system improvement of the main body of engineering construction[J].ournal of Civil Engineering, 2011, (8):147-154,in chinese. 